\title{
How to encourage children to live healthy lives? A prophylactic and health-oriented campaign called "Let's Get the Kids Moving" aimed at children in Wrocław schools
}

\author{
Katarzyna Pazdro-Zastawny', Mateusz Kolator', Alicja Basiak-Rasała², Joanna Krajewska', Sara Górna \\ Michał Zatoński ${ }^{3}$, Tomasz Zatoński ${ }^{1,4}$ \\ ${ }^{1}$ Clinic of Otolaryngology Head and Neck Surgery, Wrocław Medical University, Wrocław, Poland \\ ${ }^{2}$ Chair and Department of Social Medicine, Wrocław Medical University, Wrocław, Poland \\ ${ }^{3}$ Wrocław Medical University, Wrocław, Poland \\ 4"Run for Health" Foundation (Fundacja "Biegaj dla Zdrowia"), Wrocław
}

ADDRESS FOR CORRESPONDENCE: Michał Zatoński, Wrocław Medical University, 38 Cesarzowicka St., 52-408 Wrocław, Poland, e-mail: michal.zatonski@gmail.com

The prevalence of overweight and obesity in developed countries, including Poland, is constantly increasing. Worldwide, obesity occurs in $13-23 \%$ of adults. It is estimated that $20 \%$ of children and adolescents are overweight [1]. In a nationwide survey conducted in Poland in 1994-1995, and covering a population of elementary and high school pupils, excessive body weight was present in $8.7 \%$ and obesity in $3.4 \%$ of children and adolescents aged 7-17 years [2]. Research conducted by Małecka-Tendera in 2001 among a group of Polish children aged 7-9 showed that excess body weight occurred in $15.8 \%$ of girls and $15.0 \%$ of boys, while $3.7 \%$ of girls and $3.6 \%$ of boys were affected by obesity. This indicates a significant increase in overweight and obesity in the examined age group in comparison to the results of research from the early 1990s, conducted by the Institute of Mother and Child [3].

Children with excessive body mass are at increased risk of becoming obese as adults, and presumably will develop comorbidities [1]. It has been established that overweight and obesity in childhood is the most common risk factor for the development and premature onset of cardiovascular diseases, and that they are strongly connected with a higher risk of insulin resistance and type 2 diabetes mellitus, hypertension, dyslipidemia, cardiovascular disease, stroke, sleep apnea, gallbladder disease, hyperuricemia and gout, and osteoarthritis. Obesity is also associated with higher prevalence of certain can- cers, including colorectal and prostate cancer in men and endometrial, breast, and gallbladder cancer in women [4, 5]. Excessive body mass is also associated with substantial increase in mortality from all causes, in particular, cardiovascular diseases [6]. Kelsey et al. stated that the health effects related to excessive body mass in childhood may have long-term sequelae in adulthood - despite normalization of body mass - and, consequently, may increase the likelihood of premature morbidity and mortality [7].

Increased access to processed foods, elevated diet-energy density, and limited physical activity in children are main factors contributing to excessive weight gain. Those trends suggest the need to introduce prevention programs targeting pre-school children and their families. The main aim is to prevent overweight and obesity in children, and to improve their health via:

- promotion of a healthy lifestyle and physical activity,

- introduction of healthy diets, including changes in the consumption of fruits and vegetables, water, and limiting sugar-sweetened beverages,

- adequate and appropriate advertising for food products, especially for children,

- reduction of sedentary lifestyle, especially screenbased activities.

Studies revealed that interventions focusing on improving physical activity can reduce the risk of obesity in children aged 6 to 12 years, and adolescents aged 13 to 18 years [8]. 


\section{PROJECT}

"Let's Get the Kids Moving" ("Uruchamiamy dzieciaki") is an obesity prevention project launched in 2016 and created by the employees of Wrockaw Medical University and the "Run for Health" Foundation (Fundacja "Biegaj dla Zdrowia"). It is addressed to physical education teachers, parents, and tutors and trainers of primary school pupils. The aim of the program is to draw attention to the problem of overweight and obesity in children. „Let's Get the Kids Moving” was designed to support school environments and families by introducing ideas of healthy lifestyle, especially physical activity and healthy diet. To date, two editions of the program have been held: 2016/2017 and 2017/2018.

The aim of the project is to reduce the risk of weight gain and evaluate factors and comorbidities associated with childhood obesity by organizing sporting events and educating teachers and parents during periodic meetings.

The program's main domains include: 1) diagnostics, 2) therapy, and 3) prevention. Objectives and intervention strategies are detailed in Table 1. Diagnostics included a survey addressed to parents or legal guardians of primary school children in Wrocław, Poland. The original questionnaire was designed especially for this study by staff of the Wrocław Medical University and "Run for Health" Foundation, in order to determine the prevalence and socio-health conditions leading to overweight and obesity. The survey was divided into three parts, regarding 1) physical activity, 2) nutritional habits, and 3) health status. It was distributed to school coordinators and handed out to parents during periodic school meetings. In cooperation with the „Light Schoolbag" ("Lekki Tornister") campaign, research was also conducted on posture dysfunction in children, and we verified the actual weight of their school backpacks. In the 2016/2017 edition, parents of 2,913 children aged between 6 and 17 years and recruited from 34 ele- mentary and junior high schools in the city of Wrocław - completed and returned the questionnaire (29\% response rate). Results from the 2017/2018 edition are currently being developed.

The therapeutic part of the program involved a special training led by physical education teachers in elementary schools. A running competition was conducted in each school in the form of the Cooper's test, a 12-minute run used for basic examination of general physical fitness. The test takes place on a soft or tartan surface at an athletics stadium. Distances are clearly and accurately marked every $100 \mathrm{~m}$. All participants are supposed to run at a fairly steady pace and finish the test clearly tired. Special tables contain results based on age and sex. Winners are awarded in each age category and receive diplomas and medals from the Wrocław Medical University Run (Bieg Uniwersytetu Medycznego we Wrocławiu BUMWRO) (Photo 1).

The prevention aspect involved a series of lectures addressed to nutrition specialists, educators, physical education teachers, and parents. The lecturers were nutritionists and trainers employed by the Wrockaw Medical University.

The long-term aims of the intervention were to:

1) reduce overweight and obesity prevalence in children,

2) improve child general health and well-being,

3) promote child and family healthy eating behavior, increase child physical activity, and reduce sedentary behavior,

4) improve knowledge among school teachers, especially in terms of strategies for healthy eating and physical activity,

5) originate changes in school and home environments.

As part of the "Let's Get the Kids Moving" 2016/2017 and 2017/2018 editions, we organized:

- six open scientific conferences devoted to the problem of overweight and obesity,

TABLE 1. "Let's Get the Kids Moving" program objectives and intervention strategies

\begin{tabular}{|l|l|l|}
\hline Domains & Program objectives & Program interventions \\
\hline Diagnostics & $\begin{array}{l}\text { To establish sustainable cooperation } \\
\text { and partnership between schools, } \\
\text { parents/legal guardians and school } \\
\text { teachers and children }\end{array}$ & $\begin{array}{l}\text { Survey study examining lifestyle factors among population } \\
\text { of elementary school children. Children's parents/legal } \\
\text { guardians responded to a multidisciplinary questionnaire } \\
\text { that requested information on nutritional status, eating } \\
\text { habits, physical activity and health status: especially the } \\
\text { prevalence of otorihinolaryngological diseases of their } \\
\text { children }\end{array}$ \\
\hline Therapy & $\begin{array}{l}\text { To create supportive school and } \\
\text { family environments which promote } \\
\text { the healthy lifestyle: physical activity }\end{array}$ & $\begin{array}{l}\text { A recovery program, a training led by physical education } \\
\text { teachers of elementary schools }\end{array}$ \\
\hline Prevention & $\begin{array}{l}\text { To develop strategies to promote } \\
\text { healthy lifestyle in order to prevent } \\
\text { excessive weight gain primary in } \\
\text { schools students }\end{array}$ & $\begin{array}{l}\text { A series of lectures addressed to nutrition specialists, } \\
\text { educators, physical education teachers and parents }\end{array}$ \\
\hline
\end{tabular}




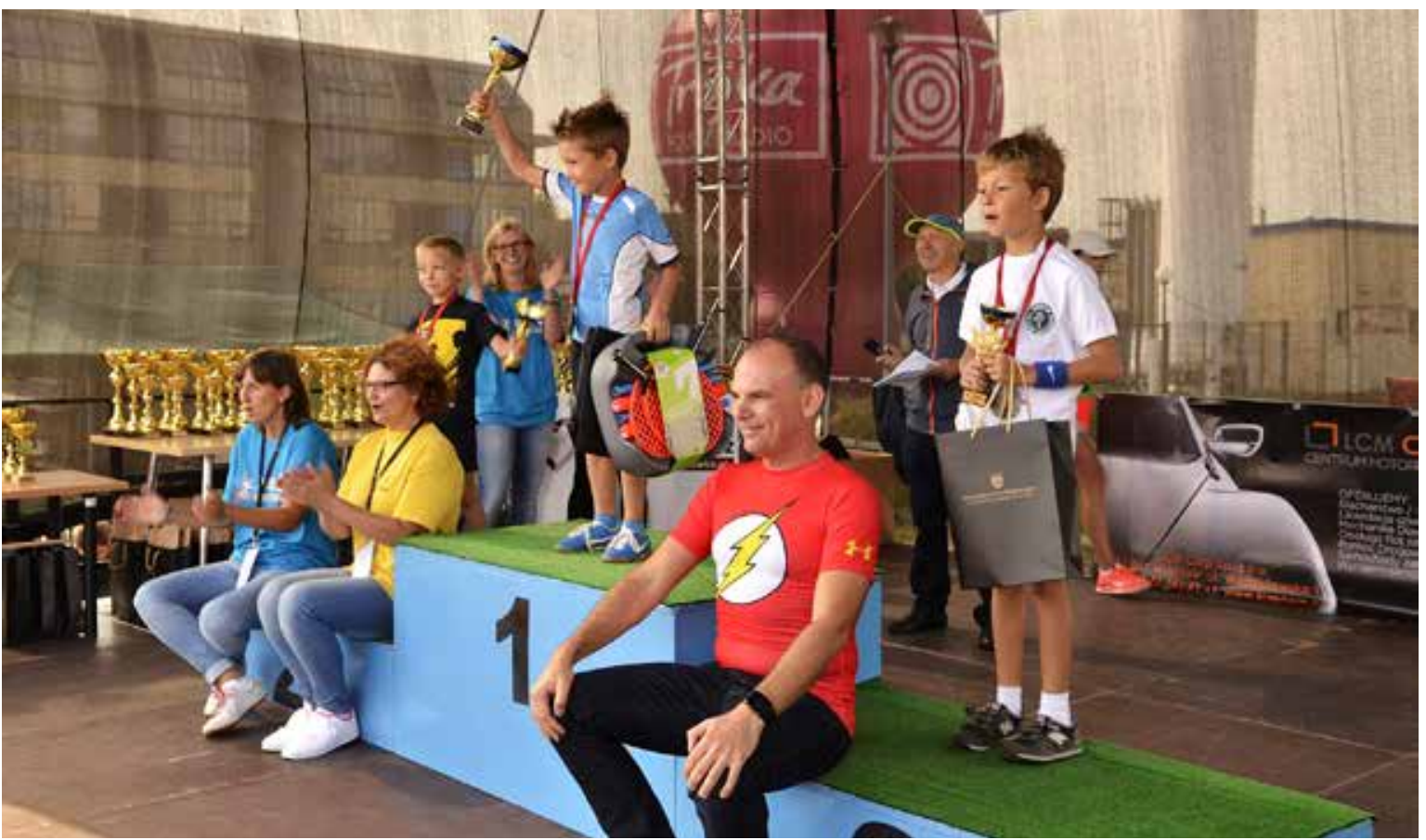

PHOTO 1. Medal ceremony during the BUMKIDS - Medical University Run Kids Edition sports event



PHOTO 2. The action final, which took place during the May sports festival of the Academy of Physical Education in Wrocław called "Przewietrz się na Olimpijskim" ("Get some air at the Olympic Stadium")

- Medical University Run, Kids Edition (BUMKIDS) - over 400, 800 and 1200 meters, held during the Wrocław Medical University Run in 2017 and 2018,

- a survey addressed to the parents of 20,000 children $(2 \times 10,000)$ from Wrocław primary schools to assess the prevalence and socio-health conditions of overweight and obesity in children,

- the final action, which took place during the May sports festival at the Academy of Physical Education in Wrocław, called „Get some air at the Olympic Stadium" ("Przewietrz się na Olimpijskim"), where competitions were held in running, basketball, volleyball, handball, and football (Photo 2),

- a press conference presenting the results obtained in the survey.

Based on the experience gained during the „Let's Get the Kids Moving" program, the authors developed proj- ect PICTURE (PopulatIon CohorT StUdy of WRocław CitizEns). Recruitment for the project (1250 children and 1250 adults) started in November 2019.

\section{ACKNOWLEDGEMENTS}

"Let's Get the Kids Moving" was supported by the Wrocław University Clinical Hospital and Jarosław Delewski from the City Hall Department of Education. Co-organizers of the action included: The Academy of Physical Education in Wrocław (prof. Andrzej Rokita, rector), the Youth Sports Center (Wojciech Gęstwa, director), and The Klanza Foundation. The program received the patronage of both the former and present Mayor of Wrocław, Rafał Dutkiewicz and Jacek Sutryk, as well as the honorary patronage of the Consulate of the Kingdom of Norway in Wrockaw. The main partner is the "Light 
Schoolbag" campaign, a program of prevention of posture defects in children organized by the Rosa Foundation.

\section{DISCLOSURE}

The author reports no conflict of interest.

\section{References}

1. WHO. Report of the Commission on Ending Childhood Obesity: implementation plan: executive summary, WHO 2017. Available from: https://www.who.int/end-childhood-obesity/publications/echo-plan-executive-summary/en/ (accessed: 10 January 2019).

2. Kułaga Z, Grajda A, Gurzkowska B, et al. The prevalence of overweight and obesity among Polish school-aged children and adolescents. Przegl Epidemiol 2016; 70 (4): 641-651.

3. Małecka-Tendera E, Klimek K, Matusik P, et al. Obesity and overweight prevalence in Polish 7- to 9-year-old children. Obes Res 2005; 13 (6): 964-968.

4. Stunkard AJ. Current views on obesity. Am J Med 1996; 100 (2): 230-236.

5. Apovian CM. Obesity: definition, comorbidities, causes, and burden. Am J Manag Care 2016; 22 (Suppl 7): 176-185.

6. Stańczyk J, Kierzkowska B, Podolec P, et al. Polish forum for prevention guidelines on cardiovascular diseases prevention in children and adolescents. Kardiol Pol 2010; 68 (5): 605-608.

7. Kelsey MM, Zaepfel A, Bjornstad P, Nadeau KJ. Age-related consequences of childhood obesity. Gerontology 2014; 60 (3): 222-228.

8. Brown T, Moore TH, Hooper L, et al. Interventions for preventing obesity in children. Cochrane Database Syst Rev 2019; 7 (4): CD001871.

\section{AUTHORS' CONTRIBUTIONS}

$K P Z, M K, A B R$, JK SG, MZ, and TZ contributed to the design and implementation of the research, to the analysis of the results and to the writing of the manuscript. 